
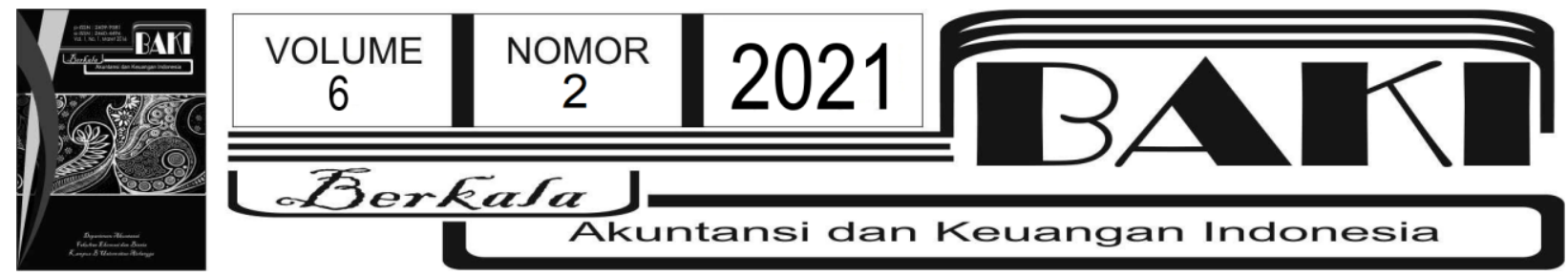

\title{
THE EFFECT OF PROPPING ON THE PERFORMANCE OF MANUFACTURING COMPANIES IN INDONESIA
}

\section{PENGARUH PROPPING TERHADAP KINERJA PERUSAHAAN MANUFAKTUR DI INDONESIA}

\author{
Supatmi Supatmi ${ }^{1^{*}}$, Steppani Steppani ${ }^{2}$ iD \\ 1,2 Satya Wacana Christian University \\ 1 *corresponding author: Supatmi.supatmi@uksw.edu
}

INFOARTIKEL ABSTRACT

Histori Artikel:

Tanggal Masuk 7 Maret 2021

Revisi Diterima 24 Maret 2021

Tanggal Diterima 30 Agustus 2021

Tersedia Online 6 September 2021

Keywords:

Company

Propping

Transaction

Performance,

$R A C T$

This study aims to find empirical evidence of the impact of proppingrelated party transactions on company performance. The research sample was manufacturing companies listed on the IDX during 20172019 which were determined by purposive sampling and using the Generalized Least Square panel data regression analysis technique (cross-section weights). The results showed that propping (related party transactions related to account payables) had a positive effect on financial performance and had a negative effect on the company's market performance. Propping (related party transactions related to other payables) had a positive effect on the company's financial performance but doesn't an affect on the company's market performance. Meanwhile, propping (related party transactions related to liabilities other than account payables) had a negative effect on financial performance but had a positive effect on the company's market performance.

Kata Kunci:

Kinerja Perusahaan,

Propping, Transaksi Pihak Berelasi

\section{A B S TRAK}

Penelitian ini bertujuan untuk menemukan bukti empiris dampak transaksi pihak berelasi bersifat propping terhadap kinerja perusahaan. Sampel penelitian merupakan perusahaan manufaktur yang tercatat di BEl 2017-2019 yang ditentukan secara purposive sampling dan menggunakan teknik analisis regresi data panel Generalized Least Square (cross-section weights). Hasil penelitian menunjukkan bahwa propping (transaksi pihak berelasi terkait utang usaha) berdampak positif terhadap kinerja keuangan dan berdampak negatif terhadap kinerja pasar perusahaan. Propping (transaksi pihak berelasi terkait utang lain-lain) berdampak positif terhadap kinerja keuangan perusahaan namun tidak berdampak terhadap kinerja pasar perusahaan. Sementara itu, propping (transaksi pihak berelasi 
terkait liabilitas selain utang usaha) berdampak negatif terhadap kinerja keuangan namun berdampak positif terhadap kinerja pasar perusahaan.

Berkala Akuntansi dan Keuangan Indonesia p-ISSN: 2459-9581; e-ISSN 2460-4496 DOI: $10.20473 /$ baki.v6i2.25839

Open access under Creative Common Attribution-Non Commercial-Share A like 4.0 International Licence (CC-BY-NC-SA) @(1) @()

\section{Pendahuluan}

Pada dasarnya keberhasilan suatu perusahaan dijelaskan oleh kinerjanya selama periode waktu tertentu untuk menarik perhatian pemangku kepentingan atau stakeholders. Kinerja perusahaan dapat berupa kinerja keuangan maupun kinerja non keuangan dengan pengukuran basis akuntansi dan pengukuran basis pasar. Pengukuran basis akuntansi umumnya dianggap sebagai indikator efektif dari profitabilitas perusahaan dan bisnis dalam jangka pendek seperti return on asset (ROA) dan return on equity ( $R O E)$, sedangkan pengukuran basis pasar dikategorikan sebagai jangka panjang dan dicirikan sebagai cerminan tentang kinerja masa depan perusahan yang diharapkan pemegang saham dan didasarkan pada kinerja sebelumnya atau saat ini, misalnya Tobin's $Q$, market value added (MVA) dan market to book value (MTBV) (Al-matari et al., 2014).

Kinerja perusahaan dapat dilihat dalam laporan keuangan yang dilaporkan perusahaan tetapi laporan keuangan rentan terhadap konflik agensi dan salah satu transaksi yang berpotensi menyiratkan masalah agensi tinggi adalah transaksi pihak berelasi (Supatmi et al., 2019). Berdasarkan data aksi korporasi dalam laporan triwulan dari Otoritas Jasa Keuangan (OJK) selama tahun 2017-2019 menunjukkan bahwa perusahaan yang terdaftar di Indonesia paling sering melakukan transaksi pihak berelasi atau transaksi terafiliasi. Dibandingkan dengan aksi korporasi lainnya, rata-rata perusahaan melakukan transaksi pihak berelasi sebanyak 50,37 persen (2017), 49,74 persen (2018), dan 48,10 persen (2019).

(Wong et al.,2015) menyatakan bahwa transaksi pihak berelasi berfungsi sebagai sarana umum untuk bisnis normal operasi dan alokasi sumber daya di antara perusahaan terafiliasi dalam kelompok bisnis yang sama. Transaksi pihak berelasi dikategorikan menjadi dua, yaitu bersifat tunneling dan propping (Cheung et al.,2009). Lebih lanjut dinyatakan (Cheung et al.,2009) tunneling merupakan transaksi piutang kepada pihak terkait dengan melakukan pengalihan sumber daya dari perusahaan untuk kepentingan pemegang saham pengendali, sedangkan propping merupakan transaksi pinjaman dari pihak terkait yang cenderung menambah nilai perusahaan. Dijelaskan juga bahwa transaksi propping memiliki karakteristik pengungkapan informasi yang lebih banyak dan diduga memengaruhi kinerja perusahaan karena mampu mendorong nilai perusahaan dibandingkan dengan transaksi tunneling yang cenderung menurunkan nilai perusahaan (Cheung et al.,2009). Ada dua kategori transaksi yang berpotensi propping, yaitu penerimaan uang tunai yang melibatkan bantuan 
tunai langsung atau pinjaman yang diberikan oleh entitas terkait kepada perusahaan yang terdaftar dan transaksi antara perusahaan terbuka dengan salah satu anak perusahaan yang tidak terdaftar (Cheung et al.,2009).

Beberapa hasil bukti empiris sebelumnya, (Cheung et al.,2009) menemukan bahwa pemegang saham minoritas dapat dikendalikan pemegang saham mayoritas untuk memaksimumkan kekayaan pribadi dari transaksi antar pihak berelasi bersifat tunneling maupun propping sehingga menurunkan kinerja perusahaan dengan menggunakan pengukuran ROA, market-to-book equity, dan Tobin's Q. Chien dan Hsu (2010) membuktikan bahwa transaksi pihak berelasi mempunyai pengaruh secara negatif terhadap kinerja perusahaan yang diukur ROA dan dimitigasi oleh prosedur tata kelola perusahaan yang baik. Sementara itu, (Jia et al.,2013) menemukan bahwa transaksi pihak terkait perusahaan publik dengan kelompok bisnisnya di Cina lebih banyak berbasis pinjaman yang membantu perusahaan publik untuk meningkatkan kinerjanya.

Dengan menggunakan sampel perusahaan di Indonesia, (Tambunan et al.,2017) menemukan bahwa transaksi terkait utang maupun piutang kepada pihak berelasi mempunyai pengaruh secara negatif terhadap kinerja perusahaan yang diukur menggunakan Tobin's $Q$ dan price book value. Sementara itu, dengan menggunakan sampel perbankan di Indonesia, (Supatmi et al., 2019) menemukan bahwa transaksi terkait dengan utang kepada pihak berelasi yang dimoderasi oleh indeks koneksi politik secara positif memengaruhi kinerja pasar perusahaan dengan menggunakan Tobin's $Q$ tetapi memberikan pengaruh negatif pada kinerja keuangan perusahaan dengan menggunakan loan to deposit ratio (LDR). Ini memberikan makna bahwa semakin banyak bank melakukan transaksi pihak berelasi yang berkaitan dengan utang dan lebih banyak memiliki koneksi politik, semakin tinggi kemampuan bank dan kinerja pasar tetapi semakin rendah likuiditasnya.

Penelitian ini mempunyai tujuan, yaitu untuk menemukan bukti empiris dampak transaksi pihak berelasi bersifat propping terhadap kinerja perusahaan. Berdasarkan penelitian sebelumnya dengan sampel penelitian di berbagai negara, termasuk Indonesia menunjukkan adanya inkonsistensi hasil penelitian tentang pengaruh transaksi pihak berelasi bersifat propping terhadap kinerja perusahaan. Inkonsistensi hasil penelitian sebelumnya menunjukkan pengaruh transaksi pihak berelasi bersifat propping ada yang berpengaruh positif maupun berpengaruh negatif, atau tidak memiliki pengaruh bagi kinerja perusahaan. Penelitian sebelumnya juga lebih banyak berfokus pada tunneling dan propping secara bersama-sama (Cheung et al.,2009; Tambunan et al.,2017; Pozzoli \& Venuti,2014; Chen \& Wu,2010) sehingga penelitian ini berfokus pada pengaruh transaksi pihak berelasi bersifat propping terhadap kinerja perusahaan. Penelitian ini dilakukan pada perusahaan manufaktur yang tercatat di Bursa Efek Indonesia (BEl) antara 2017-2019. Transaksi pihak berelasi bersifat propping akan 
diukur dengan transaksi pihak berelasi terkait utang usaha, transaksi pihak berelasi terkait utang lain-lain, dan transaksi pihak berelasi terkait liabilitas selain utang usaha. Alasan melakukan penelitian ini pada perusahaan manufaktur di Indonesia, yaitu karakteristik perusahaan di Indonesia yang terpusat pada kepemilikan keluarga rentan dengan transaksi pihak berelasi (Utama et al.,2010). Selain itu, perusahaan manufaktur merupakan sektor yang luas dengan berbagai sub sektor industri, memiliki jumlah perusahaan terbanyak, dan mendominasi perusahaan lain yang tercatat di BEI sehingga akan didapatkan gambaran dampak transaksi pihak berelasi terhadap kinerja perusahaan yang lebih luas juga dan mewakili seluruh industri di Indonesia.

Manfaat penelitian ini, yaitu memberikan tambahan bukti empiris aplikasi teori biaya transaksi khususnya dampak transaksi pihak berelasi bersifat propping terhadap kinerja perusahaan di Indonesia, khususnya industri manufaktur. Hasil penelitian ini dapat menjadi dasar pertimbangan untuk direksi (pengelola) perusahaan dalam pengambilan keputusan mengenai transaksi pihak berelasi bersifat propping. Bagi para pelaku pasar di BEI, dapat berguna untuk dasar pertimbangan dalam memahami terkait dampak transaksi pihak berelasi bersifat propping dalam perusahaan terhadap kinerjanya. Selain itu, juga dapat menjadi dasar pertimbangan bagi Bank Indonesia (BI) dan OJK dalam hal pengaturan dan pengawasan kebijakan terkait transaksi pihak berelasi di perusahaan.

\section{Tinjauan Pustaka}

\subsection{Teori Biaya Transaksi}

Teori biaya transaksi atau transaction cost theory merupakan teori yang pada mulanya digagas oleh Ronald Coase (1937) yang kemudian dikembangkan oleh Oliver Williamson (1979) melalui bukunya "Transaction Cost Economics and the Governance of Contractual Relations" (Rindfleisch, 2020). Teori ini banyak diterapkan dalam bidang pemasaran namun demikian dengan dua asumsi pentingnya tentang pelaku ekonomi, yaitu rasionalitas dan oportunisme terbatas, serta tiga dimensi kunci dari transaksi ekonomi, yaitu kekhususan aset, frekuensi, dan ketidakpastian teori ini juga diterapkan dalam bidang lainnya terkait dengan biaya transaksi.

Perspektif teori ini menurut Pagalung (2004) memandang bahwa keberhasilan suatu organisasi diukur dari kemampuan para manajer perusahaan untuk mengelola transaksitransaksi ekonomi secara efisien. Lebih lanjut dinyatakan bahwa penghematan transaction cost adalah faktor utama dalam menjelaskan kelangsungan hidup kontrak. Perspektif teori ini sejalan dengan pendapat (Gordon et al., 2004) tentang transaksi yang dilakukan perusahaan kepada pihak afiliasi. (Gordon et al., 2004) berpendapat bahwa dengan melakukan transaksi pihak 
berelasi dapat meminimalkan pengeluaran biaya transaksi sehingga meningkatkan kinerja perusahaan yang dirumuskan sebagai efficient transaction hypothesis, yaitu transaksi pihak berelasi secara efisien memenuhi kebutuhan ekonomi dasar perusahaan. Prosedur transaksi pihak berelasi relatif lebih mudah, cepat, dan mengenai harga dapat diabaikan karena hubungan istimewa yang terjalin sehingga muncul efisiensi biaya atas transaksi tersebut dan dapat mendongkrak kinerja perusahaan berupa peningkatan laba yang dihasilkan oleh perusahaan.

\subsection{Kinerja Perusahaan}

Pemegang saham mayoritas di perusahaan dapat menggunakan kekayaan pribadi untuk menopang perusahaan ketika dalam kondisi menurun melalui transaksi pihak berelasi untuk mendorong kinerja perusahaan (Cheung et al., 2009). Selain itu, untuk mendorong kinerja operasional, perusahaan akan menerima lebih banyak dukungan melalui transaksi pihak berelasi dalam bentuk pinjaman (Jia et al.,2013). Kinerja perusahaan dapat diinterpretasikan dan diukur melalui analisis rasio keuangan suatu perusahaan (Widianto,2011). Kinerja perusahaan memiliki dua jenis pengukuran (Supatmi et al.,2019). Jenis pengukuran pertama adalah ROA yang secara umum diterima dan banyak digunakan untuk ukuran kinerja operasional perusahaan yang tepat (Al-matari et al.,2014; Pozzoli \& Venuti (2014)). ROA merupakan salah satu jenis rasio untuk menganalisis laporan keuangan perusahaan dalam laporan kinerja keuangan (Kamal, 2017). Pengukuran ROA menunjukkan kemampuan investasi dalam seluruh aset dari modal untuk memeroleh laba (Kamal, 2017). Pozzoli dan Venuti (2014) mengatakan bahwa ROA adalah rasio yang sesuai untuk mengidentifikasi kinerja perusahaan, karena diterima secara umum dalam keuangan sebagai rasio yang signifikan dan dihitung tanpa mengungkapkan penilaian diskresi (kebebasan mengambil keputusan sendiri). Jenis komunitas pengukuran kedua adalah Tobin's $Q$ yang banyak digunakan untuk menilai kinerja pasar suatu perusahaan (Al-matari et al., 2014), berhubungan dengan nilai perusahaan yang menunjukkan cara pihak manajemen dalam mengatur aset yang dimiliki perusahaan (Sudiyatno \& Puspitasari, 2010). Tobin's Q merupakan rasio nilai pasar perusahaan dengan biaya yang dikeluarkan untuk pergantian aset (Villalonga \& Amit, 2006). Tobin's Q digunakan untuk menghitung rasio pasar kapitalisasi ditambah jumlah nilai utang dibagi dengan jumlah nilai aset perusahaan (Al-matari et al., 2014).

\subsection{Propping}

(Cheung et al., 2009) mengemukakan bahwa transaksi pihak berelasi didefinisikan sebagai transfer dari kewajiban atau sumber daya antara perusahaan terbuka atau anak perusahaannya dan pihak terkait. Pihak terkait dapat berupa badan hukum atau perorangan, 
secara langsung atau tidak langsung mengendalikan perusahaan. Transaksi ini biasanya merupakan transaksi bisnis yang saling berhubungan antara manajer, direktur atau pemilik utama dengan perusahaan (Gordon et al.,2004). Transaksi pihak berelasi juga bisa dilakukan terkait dengan aset, kewajiban, penjualan, dan beban (Utama et al.,2010). Berdasarkan Peraturan Otoritas Jasa Keuangan Nomor 42/POJK.04/2020 tentang Transaksi Afiliasi dan Benturan Kepentingan Transaksi Tertentu (Otoritas Jasa Keuangan, 2020) menyatakan bahwa transaksi afiliasi merupakan setiap aktivitas dan/atau transaksi yang dilakukan oleh perusahaan terbuka atau perusahaan terkendali dengan afiliasi dari perusahaan terbuka atau afiliasi dari anggota direksi, anggota dewan komisaris atau pemegang saham utama, atau pengendali, termasuk setiap aktivitas dan/atau transaksi yang dilakukan oleh perusahaan terbuka atau perusahaan terkendali untuk kepentingan afiliasi dari perusahaan terbuka atau afiliasi dari anggota direksi, anggota dewan komisaris, pemegang saham utama, atau pengendali.

Propping merupakan transaksi pihak berelasi yang dapat berdampak positif bagi perusahaan, yaitu mendorong kinerja perusahaan (Cheung et al., 2009) karena salah satunya adalah ada efisiensi biaya transaksi dalam transaksi antar pihak berelasi (Gordon et al.,2004). Propping merupakan transaksi yang akan menguntungkan bagi perusahaan publik, misalnya penerimaan kas atau jaminan pinjaman dari pemegang saham pengendali sehingga perusahaan akan diuntungkan dari transaksi tersebut (Cheung et al., 2009). Propping dianggap sebagai mekanisme untuk melestarikan aset perusahaan (Friedman, Johnson, \& Mitton, 2003). Tambunan et al. (2017) mengatakan bahwa pola propping menunjukkan efek, yaitu menopang yang meningkatkan nilai perusahaan. Melalui propping dalam bentuk transaksi pinjaman atau utang memiliki dampak langsung adalah untuk meningkatkan potensi menopang dan membuat investor berpartisipasi dalam pembiayaan perusahaan (Tambunan et al.,2017). Selain itu, transaksi pihak berelasi bersifat propping digunakan untuk manajemen laba dan meningkatkan efisiensi operasi perusahaan berupa biaya transaksi pembelian atau penjualan aset dan pembayaran tunai kepada pihak berelasi (Wong et al.,2015). Meningkatkan efisiensi operasi perusahaan ini dilakukan dengan mengalokasikan sumber daya di antara afiliasi perusahaan dalam kelompok bisnis yang sama sehingga nilai perusahaan meningkat (Wong et al.,2015).

\subsection{Pengembangan Hipotesis}

\subsubsection{Propping dan kinerja keuangan perusahaan}

Ada dua kategori transaksi yang berpotensi propping, yaitu penerimaan uang tunai yang melibatkan bantuan tunai langsung atau pinjaman yang diberikan oleh entitas terkait sehingga dapat membantu dalam mendanai proyek dan mendorong aktivitas perusahaan (Cheung et al., 2009). Perusahaan go public akan menerima lebih banyak dukungan dalam bentuk pinjaman melalui transaksi pihak berelasi sehingga membantu meningkatkan kinerja perusahaan (Jia et 
al., 2013). Selain itu, perusahaan terbuka yang melakukan transaksi penjualan dengan salah satu anak perusahaan yang tidak tercatat di bursa efek (Cheung et al., 2009). Transaksi penjualan dengan pihak berelasi sering kali melibatkan ketentuan harga yang menguntungkan atau transaksi rendah biaya sehingga dapat membantu meningkatkan penjualan maupun harga dan berdampak pada kinerja (laba) perusahaan meningkat (Jian \& Wong, 2010).

Penelitian sebelumnya, Jia et al. (2013) menyatakan bahwa perusahaan go public di negara China menerima banyak dukungan dalam bentuk transaksi pihak berelasi non-pinjaman (perusahaan go public membeli dengan harga tertentu atau diskon dan penjualan barang dengan harga premium kepada pihak berelasi) ketika kinerja perusahaan mengalami penurunan untuk membantu mendongkrak kinerja perusahaan yang diukur dengan menggunakan ROA maupun ROE. Hasil penelitian terdahulu, ditemukan bahwa transaksi pihak berelasi bersifat propping mempunyai pengaruh secara negatif terhadap kinerja perusahaan yang diukur ROA (Cheung et al., 2009; Chien \& Hsu, 2010). Utama et al. (2010) menemukan bahwa tidak ada pengaruh transaksi pihak berelasi pinjaman terhadap kinerja perusahaan yang diukur ROA, sedangkan pada penelitian Kohlbeck dan Mayhew (2010) dan Gordon et al. (2004) menunjukkan bahwa transaksi pihak berelasi terkait pemberian pinjaman berpengaruh positif untuk meningkatkan kinerja keuangan perusahaan melalui praktik manajemen laba. Oleh sebab itu, penelitian ini memprediksi transaksi bersifat propping yang dijalankan oleh perusahaan kepada pihak berelasi dapat menaikkan kinerja keuangan perusahaan dan rumusan hipotesis sebagai berikut:

\section{$\mathrm{H}_{1}$ : Propping berpengaruh positif terhadap kinerja keuangan perusahaan}

\subsubsection{Propping dan kinerja pasar perusahaan}

Transaksi pihak berelasi dapat memberikan dampak kepada pemegang saham mayoritas di perusahaan yang memiliki kekuatan untuk mengambil alih pemegang saham minoritas (Cheung et al., 2009). Namun, melakukan transaksi dengan pihak afiliasi bersifat propping dapat meningkatkan efisiensi biaya transaksi (Gordon et al., 2004). Meningkatkan efisiensi biaya perusahaan dilakukan dengan mengalokasikan sumber daya di antara afiliasi perusahaan dalam kelompok bisnis yang sama (Wong et al.,2015). Efisiensi biaya tersebut dilakukan untuk menaikkan laba sehingga dapat mendorong kinerja perusahaan (Triyono, 2020). Kinerja perusahaan direpresentasikan melalui pengungkapan informasi dalam bentuk laporan keuangan (Supatmi et al., 2019). Ketika perusahaan menunjukkan kinerja yang baik melalui pengungkapan informasi maka pasar akan menunjukan informasi tersebut sehingga shareholders akan tertarik dan nilai pasar perusahaan meningkat (Triyono, 2020).

Hasil penelitian Wong et al. (2015) ditemukan bahwa transaksi pihak berelasi terkait penjualan yang tidak normal (abnomal sales) mempunyai dampak positif atas kinerja 
perusahaan yang diukur Tobin's $Q$. Transaksi terkait dengan pinjaman kepada pihak berelasi yang dimoderasi oleh indeks koneksi politik secara positif memengaruhi kinerja pasar yang dihitung dengan Tobin's Q (Supatmi et al.,2019). Akan tetapi, pada penelitian lainnya menemukan bahwa transaksi pihak berelasi terkait pinjaman dapat menurunkan kinerja pasar perusahaan (Jian \& Wong, 2010; Tambunan et al.,2017). Dengan Demikian, penelitian ini memprediksi transaksi bersifat propping yang dijalankan oleh perusahaan kepada pihak berelasi dapat menaikkan kinerja pasar perusahaan dan dirumuskan hipotesis sebagai berikut:

\section{$\mathrm{H}_{2}$ : Propping berpengaruh positif terhadap kinerja pasar perusahaan}

\section{Metodologi Penelitian}

\subsection{Populasi dan Sampel Penelitian}

Populasi penelitian ini ialah perusahaan manufaktur yang tercantum di BEI antara tahun 2017 hingga 2019. Purposive sampling dengan menggunakan kriteria berdasarkan pertimbangan (judgement) untuk menentukan sampel pada penelitian ini meliputi:

1. Menerbitkan laporan tahunan secara berurutan dari 2017 sampai 2019.

2. Tanggal pelaporan laporan keuangan berakhir pada 31 Desember setiap tahunnya.

3. Memiliki informasi harga pasar saham penutupan pada akhir tahun.

Data penelitian ini menggunakan laporan tahunan perusahaan manufaktur selama 2017-2019 (data sekunder) yang didapatkan dari www.idx.co.id.

\subsection{Pengukuran Variabel Penelitian}

Penelitian ini memiliki variabel kontrol, variabel independen dan variabel dependen. Variabel dependen (kinerja perusahaan) akan diukur dengan dua pengukuran, yakni kinerja keuangan perusahaan diproksikan dengan ROA dan kinerja pasar perusahaan diproksikan dengan Tobin's Q. ROA diukur dengan membagikan laba bersih yang dimiliki perusahaan dengan nilai total aset perusahaan (Berkman, Cole, \& Fu, 2009). Sedangkan, Tobin's $Q$ diukur dengan kapitalisasi pasar ditambah total nilai utang dalam pembukuan perusahaan pada akhir tahun lalu dibagi total nilai buku aset perusahaan pada akhir tahun (Berkman et al., 2009)

Variabel independen dalam penelitian adalah transaksi pihak berelasi bersifat propping (PP) dengan mengacu pada (Cheung et al., 2009) dan (Jian \& Wong, 2010) sebagai berikut:

1. Jumlah nilai transaksi pihak berelasi utang usaha yang disajikan di laporan keuangan dibagi dengan total liabilitas (RPT UU). 
2. Jumlah nilai transaksi pihak berelasi utang lain-lain yang disajikan di laporan keuangan dibagi dengan total liabilitas (RPT ULL).

3. Jumlah nilai transaksi pihak berelasi liabilitas selain utang usaha yang disajikan di laporan keuangan dibagi dengan total liabilitas (RPT LSU)

Variabel kontrol digunakan untuk mengendalikan hubungan variabel independen dan variabel dependen, karena konsisten dapat memengaruhi variabel independen (Yuliyanti, 2019). Variabel kontrol penelitian ada tiga, yakni ukuran perusahaan, leverage, dan kepemilikan manajerial. Ketiga variabel kontrol tersebut tercantum dalam penelitian ini karena banyak digunakan pada penelitian sebelumnya (Supatmi, 2020) dan konsisten memengaruhi kinerja perusahaan baik secara positif maupun negatif (Cheung et al., 2009; Wong et al., 2015; Utama et al., 2010;). Ukuran perusahaan, yaitu skala suatu perusahaan yang dapat diperhatikan melalui jumlah nilai aset, total penjualan, dan kapitalisasi pasar (Apriansyah, 2016). Ukuran perusahaan (UP) dihitung dengan cara logaritma kapitalisasi pasar ekuitas perusahaan (Utama et al., 2010). Leverage (LV), yaitu rasio yang dipakai untuk mengukur sejauh mana utang milik perusahaan dimanfaatkan untuk membiayai aset (Luh et al., 2016). Leverage dihitung dengan cara membagikan total utang atau liabilitas perusahaan dengan total aset (Berkman et al., 2009). Kepemilikan manajerial (KM), yaitu kondisi perusahaan ketika manajer secara bersamaan sebagai pemegang saham perusahaan yang dijelaskan dalam catatan atas laporan keuangan (Christiawan \& Tarigan, 2005). Kepemilikan manajerial dihitung dengan persentase jumlah saham pihak manajemen (jumlah saham komisaris, manajer dan direksi dibagi total saham perusahaan yang beredar) dari catatan atas laporan keuangan di laporan keuangan tahunan (Agusti \& Pramesti, 2009).

\subsection{Teknik Analisis}

Teknik analisis regresi data panel Generalized Least Square (cross-section weights) digunakan pada penelitian ini untuk pengujian hipotesis dan diolah dengan program Eviews 10. Gujarati dan Porter (2009: 237) menyatakan bahwa data panel yang menggunakan metode generalized least square diasumsikan telah memenuhi atau lulus uji asumsi klasik dan tidak perlu dilakukan uji asumsi klasik karena data panel dapat memberi lebih banyak informasi, variasi, derajat kebebasan, dan mengurangi kemungkinan timbulnya bias dalam hasil analisis. Pengujian hipotesis dengan persamaan regresi sebagai berikut:

$$
\begin{array}{ll}
\text { ROA }_{i t} & =\beta_{\mathrm{oit}}+\beta 1 \mathrm{PP}_{i t}+\beta 2 \mathrm{UP}_{\mathrm{it}}+\beta 3 \mathrm{LV}_{\mathrm{it}}+\beta 4 \mathrm{KM}_{\mathrm{it}}+\varepsilon \\
\text { TOBIN'S Q }_{i t} & =\alpha \mathrm{O}_{\mathrm{it}}+\alpha 1 \mathrm{PP}_{\mathrm{it}}+\alpha 2 \mathrm{UP}_{\mathrm{it}}+\alpha 3 \mathrm{LV}_{\mathrm{it}}+\alpha 4 \mathrm{KM}_{\mathrm{it}}+\varepsilon
\end{array}
$$


Berdasarkan hasil pengujian tersebut maka untuk hipotesis 1 dan 2, yaitu transaksi pihak berelasi bersifat propping berpengaruh positif terhadap kinerja keuangan dan kinerja pasar perusahaan akan dinyatakan diterima dengan hipotesis statistik sebagai berikut:

$\mathrm{H}_{0}: \alpha 1$ dan $\beta 1 \leq 0$

Ha: $\alpha 1$ dan $\beta 1>0$

Penerimaan hipotesis atas seluruh pengujian di atas akan menggunakan tingkat kepercayaan atau signifikansi sebesar $5 \%$.

\section{Hasil dan Pembahasan}

\subsection{Penentuan Sampel Penelitian}

Populasi penelitian ini merupakan perusahaan manufaktur yang tercatat di BEI selama tahun 2017-2019 berjumlah 191 perusahaan. Sampel penelitian ditentukan secara purposive sampling dengan penentuan sebagai berikut:

Tabel 4.1

\section{Sampel Penelitian}

\begin{tabular}{lc}
\hline \multicolumn{1}{c}{ Kriteria } & $\begin{array}{c}\text { Jumlah } \\
\text { Perusahaan }\end{array}$ \\
\hline Perusahaan manufaktur yang tercatat di BEI tahun 2017-2019 & 191 \\
Perusahaan yang tidak menerbitkan laporan tahunan 2017-2019 & $(41)$ \\
secara berturut-turut. & \\
Perusahaan yang tanggal laporan keuangannya tidak berakhir & $(0)$ \\
pada 31 Desember & \\
Perusahaan yang tidak memiliki informasi harga saham & $(25)$ \\
\hline Total sampel yang memenuhi kriteria & $\mathbf{1 2 5}$ \\
\hline Sumber: Data diolah (2021) &
\end{tabular}

Penelitian ini mengunakan data perusahaan manufaktur yang mencakup beberapa sektor, yakni industri dan kimia, aneka industri dan industri barang konsumsi. Sampel penelitian sejumlah 125 atau 375 jumlah observasi penelitian (firm years).

\subsection{Statistika Deskriptif}

Statistika deskriptif dilakukan untuk menunjukkan gambaran perilaku dan distribusi data sampel yang terdiri dari penghitungan nilai maksimum, minimum, rata-rata atau mean dan standar deviasi sebagai berikut:

Tabel 4.2 
Statistika Deskriptif

\begin{tabular}{lcccc}
\hline $\begin{array}{c}\text { Variabel } \\
\text { Penelitian }\end{array}$ & $\begin{array}{c}\text { Nilai } \\
\text { Maksimum }\end{array}$ & $\begin{array}{c}\text { Nilai } \\
\text { Minimum }\end{array}$ & $\begin{array}{c}\text { Nilai } \\
\text { Rata-Rata }\end{array}$ & $\begin{array}{c}\text { Standar } \\
\text { Deviasi }\end{array}$ \\
\hline ROA & 0,92 & $-0,67$ & 0,05 & 0,11 \\
TOBINS & 35,40 & 0,36 & 1,99 & 3,32 \\
RPT UU & 0,82 & 0,00 & 0,04 & 0,09 \\
RPT ULL & 0,52 & 0,00 & 0,01 & 0,05 \\
RPT LSU & 0,52 & 0,00 & 0,03 & 0,08 \\
UP & 33,94 & 23,33 & 28,14 & 2,16 \\
LV & 5,07 & 0,00 & 0,51 & 0,49 \\
KM & 0,85 & 0,00 & 0,06 & 0,15 \\
\hline
\end{tabular}

Keterangan:

ROA: Return on assets; TOBINS: Nilai Tobin's Q; RPT UU: Transaksi Pihak Berelasi Utang Usaha; RPT ULL: Transaksi Pihak Berelasi Utang Lain-Lain; RPT LSU; Transaksi Pihak Berelasi Liabilitas Selain Utang Usaha; UP: Ukuran perusahaan; LV: Leverage; KM: Kepemilikan Manajerial.

Sumber: Data diolah (2021)

Berdasarkan Tabel 2, perusahaan yang menjadi sampel penelitian memiliki rata-rata ROA senilai 0,05 artinya perusahaan mampu memeroleh return atau laba dari aset yang dimiliki pada tahun 2017-2019 sebesar 5 persen. Nilai ROA tertinggi dimiliki PT. Merck Indonesia Tbk (MERK) yang bergerak dalam industri barang konsumsi untuk tahun 2018 dengan nilai 92 persen. Hal ini menunjukan kinerja keuangan MERK mampu menghasilkan laba bersih senilai $R p 1,16$ triliun dengan aset yang dimiliki perusahaan sebesar Rp1,26 triliun. Nilai ROA terendah dimiliki PT. Prasidha Aneka Niaga Tbk (PSDN) di tahun 2018 dengan nilai -67 persen artinya kinerja keuangan yang dimiliki oleh PSDN belum mampu menghasilkan laba bersih atau mengalami kerugian sebesar Rp465 miliar dari aset yang dimiliki perusahaan sebesar Rp697 miliar. Nilai standar deviasi ROA adalah 0,11>0,05 artinya data bervariasi.

Kinerja pasar perusahaan (Tobin's Q) memeroleh nilai rata-rata, yaitu 1,99 yang menunjukan bahwa nilai pasar perusahaan lebih tinggi jika dibandingkan dengan nilai perusahaan yang tercatat. PT. Inti Agri Resources Tbk (IIKP) memiliki nilai Tobin's Q tertinggi di tahun 2017 sebesar 35,40 dengan harga saham Rp330,00 dan jumlah saham beredar sebanyak 33.600.000.000 lembar. Sementara itu, PT. Intanwijaya Internasional Tbk (INCl) memiliki nilai Tobin's $Q$ terendah di tahun 2017 sebesar 0,36 dengan harga saham Rp408,00 dan jumlah saham beredar sebanyak 181.035.556 lembar. Nilai standar deviasi Tobin's $Q$ sebesar 3,32 lebih besar dari 1,99 yang artinya data bervariasi.

Terkait variabel transaksi pihak berelasi, Tabel 2 menunjukkan perusahaan sampel secara umum sangat kecil melakukan transaksi terkait utang usaha, transaksi terkait utang lainlain dan transaksi terkait liabilitas selain utang usaha kepada pihak berelasi. Kondisi ini dapat terlihat dari nilai secara rata-rata transaksi pihak berelasi sebesar 4 persen, 1 persen dan 3 
persen. PT. Betonjaya Manunggal Tbk (BTON) yang bergerak dalam industri dasar dan kimia memiliki nilai transaksi pihak berelasi terkait utang usaha tertinggi pada tahun 2019 dengan nilai 82 persen. Hal ini menunjukkan sebagian besar total utang yang dimiliki oleh BTON senilai Rp46 miliar berasal dari transaksi terkait utang usaha kepada pihak berelasi sebesar Rp37 miliar. Nilai transaksi terkait utang lain-lain dan liabilitas selain utang usaha kepada pihak berelasi tertinggi dimiliki PT. Polychem Indonesia Tbk (ADMG) di tahun 2017 dengan nilai 52 persen atau sebanyak Rp934 miliar dari total liabilitas yang dimiliki oleh perusahaan sebesar Rp1,822 miliar. Nilai standar deviasi transaksi pihak berelasi terkait utang usaha $(0,09)$, transaksi pihak berelasi terkait utang lain-lain $(0,05)$, transaksi pihak berelasi terkait liabilitas selain utang usaha $(0,08)$ lebih besar dari nilai rata- rata berarti data bervariasi.

Secara umum ukuran perusahaan sampel selama periode penelitian (2017-2019) memiliki nilai rata-rata sebesar 28,14 yang dilihat dari kapitalisasi pasar. Ukuran perusahaan tertinggi dimiliki PT. HM Sampoerna Tbk (HMSP) di tahun 2017 yang bernilai 33,94 dengan kapitalisasi pasar sebesar Rp550 triliun. Sedangkan, PT. Nusantara Inti Corpora Tbk (UNIT) di tahun 2019 memiliki ukuran perusahaan terendah yang bernilai 23,33 dengan kapitalisasi pasar sebesar Rp13 miliar. Nilai standar deviasi ukuran perusahaan adalah 2,16 <28,14 berarti data kurang bervariasi.

Tingkat leverage pada perusahaan sampel selama tahun 2017-2019 memiliki angka rata-rata, yaitu 0,51 artinya secara umum perusahaan membiayai aset dari utang sebesar 51 persen. PT. Asia Pacific Fibers Tbk (POLY) memiliki tingkat leverage tertinggi pada tahun 2017 dengan nilai 5,07 artinya sebagian besar total utang POLY senilai Rp15 triliun digunakan untuk membiayai aset yang dimiliki sebesar Rp3 triliun, Nilai standar deviasi leverage sebesar 0,49< 0,5 berarti data kurang bervariasi.

Kepemilikan manajerial pada sampel perusahaan memiliki nilai rata-rata, yaitu 0,06 yang secara umum berarti pihak manajemen memiliki saham sekaligus sebagai pemegang saham pada sampel perusahaan selama periode penelitian sebesar 6 persen. Nilai kepemilikan manajerial tertinggi dimiliki oleh PT. Campina Ice Cream Industry Tbk (CAMP) di tahun 2017 sebesar 0,85 artinya sebagian besar pemegang saham CAMP merupakan pihak manajemen perusahaan sebesar 85 persen. Nilai standar deviasi kepemilikan manajerial sebesar 0,15 > 0,06 berarti data bervariasi.

\subsection{Pengujian Hipotesis}

Hipotesis pada penelitian ini dilakukan pengujian dengan menggunakan teknik estimasi regresi data panel GLS (cross-section weights). Hasil pengujian hipotesis ada pada tabel 3 dibawah ini. 
Hasil Pengujian Hipotesis

\begin{tabular}{|c|c|c|c|c|c|}
\hline \multirow[t]{2}{*}{ Variabel } & \multirow[t]{2}{*}{$\begin{array}{l}\text { Prediksi arah } \\
\text { pengaruh }\end{array}$} & \multicolumn{2}{|c|}{$\begin{array}{c}\text { Kinerja perusahaan } \\
\text { berbasis akuntansi (ROA) }\end{array}$} & \multicolumn{2}{|c|}{$\begin{array}{c}\text { Kinerja perusahaan berbasis } \\
\text { pasar (TOBIN'S Q) }\end{array}$} \\
\hline & & Koefisien & Prob & Koefisien & Prob \\
\hline Konstanta & & $-0,3600$ & 0,0000 & $-14,8783$ & 0,0000 \\
\hline RPT UU & + & 0,0075 & 0,0140 & $-0,3838$ & 0,0000 \\
\hline RPT ULL & + & 0,0791 & 0,0071 & $-0,2034$ & 0,3171 \\
\hline RPT LSU & + & $-0,1175$ & 0,0000 & 1,0307 & 0,0000 \\
\hline UP & & 0,0150 & 0,0000 & 0,5825 & 0,0000 \\
\hline LV & & $-0,0170$ & 0,0000 & 0,6746 & 0,0000 \\
\hline KM & & $-0,0534$ & 0,0000 & $-0,1674$ & 0,1919 \\
\hline $\mathrm{R}^{2}$ & & 0,7602 & & 0,8991 & \\
\hline Adjusted $R^{2}$ & & 0,7563 & & 0,8974 & \\
\hline F-statistic & & 194,4959 & 0,0000 & 546,5614 & 0,0000 \\
\hline
\end{tabular}

ROA: Return on assets; TOBINS: Nilai Tobin's Q; RPT UU: Transaksi Pihak Berelasi Utang Usaha; RPT ULL: Transaksi Pihak Berelasi Utang Lain-Lain; RPT LSU; Transaksi Pihak Berelasi Liabilitas Selain Utang Usaha; UP: Ukuran perusahaan; LV: Leverage; KM: Kepemilikan manajerial.

Sumber: Data diolah (2021)

Berdasarkan tabel 3 hasil pengujian hipotesis diperoleh nilai adjusted $R^{2}$ pada variabel dependen ROA sebesar 0,7563 atau 75,63 persen artinya variabel dependen dapat diinterpretasikan oleh variabel independen sebanyak 75,63 persen dan 24,37 persen mampu dijelaskan oleh variabel independen lain yang tidak tercantum di penelitian ini. Variabel dependen Tobin's $Q$ memeroleh nilai adjusted $R^{2}$ sebesar 0,8974 atau 89,74 persen artinya variabel independen mampu menjelaskan variabel dependen sebanyak 89,74 persen dan 10,26 persen mampu diinterpretasikan oleh variabel independen lain yang tidak tercantum di penelitian ini.

Uji statistik F (uji stimultan) pada variabel dependen kinerja keuangan perusahaan yang diproksi dengan ROA diperoleh nilai probabilitas $F$-statistic $<0,05$ yang bermakna seluruh variabel independen mempunyai pengaruh signifikan terhadap variabel dependen ROA secara bersamaan. Variabel dependen kinerja pasar perusahaan yang diproksi dengan Tobin's $Q$ juga memeroleh nilai probabilitas F-statistic $<0,05$ yang bermakna bahwa variabel dependen Tobin's $Q$ dapat dipengaruhi oleh seluruh variabel independen secara bersamaan. Dengan demikian, secara statistik fungsi regresi pada pengujian hipotesis dari penelitian ini memenuhi goodness of fit model yang artinya model penelitian ini layak digunakan dalam memprediksi kinerja perusahaan.

Hasil uji t (uji parsial) berdasarkan tabel 3 diperoleh informasi bahwa propping yang diukur dengan transaksi terkait utang usaha dan transaksi terkait utang lain-lain kepada pihak berelasi dalam perusahaan manufaktur berpengaruh positif terhadap kinerja keuangan perusahaan (ROA). Dengan demikian, hipotesis 1 terdukung. Namun, propping yang diukur 
dengan transaksi pihak berelasi terkait liabilitas selain utang usaha dalam perusahaan manufaktur ditemukan berpengaruh negatif terhadap kinerja keuangan perusahaan (ROA) sehingga hipotesis tidak terdukung.

Pengujian variabel dependen kinerja pasar perusahaan (Tobin's Q) juga diperoleh informasi bahwa propping yang diukur dengan transaksi pihak berelasi terkait liabilitas selain utang usaha memiliki pengaruh positif terhadap kinerja pasar perusahaan (Tobin's Q). Dengan demikian, hipotesis 2 untuk propping yang diukur dengan transaksi pihak berelasi terkait liabilitas selain utang, terdukung. Sementara itu, propping yang diukur dengan transaksi pihak berelasi terkait utang usaha berpengaruh negatif terhadap kinerja pasar perusahaan (Tobin's Q) dan transaksi pihak berelasi terkait utang lain-lain tidak berpengaruh sehingga hipotesis 2 tidak terdukung.

Tabel 3 di atas memperlihatkan bahwa terdapat variabel lain yang memberikan pengaruh terhadap kinerja keuangan dan kinerja pasar perusahaan, yaitu ukuran perusahaan, leverage dan kepemilikian manajerial. Ukuran perusahaan ditemukan memiliki pengaruh positif terhadap ROA dan Tobin's $Q$ yang berarti semakin besar perusahaan, akan cenderung menjadi lebih baik kinerja keuangan dan kinerja pasar perusahaan. Leverage terbukti berpengaruh positif secara signifikan terhadap kinerja pasar perusahaan (Tobin's Q) berarti semakin banyak jumlah utang milik perusahaan yang digunakan untuk membiayai aset maka kinerja pasar perusahaan menjadi meningkat. Namun, leverage mempunyai pengaruh negatif secara signifikan pada kinerja keuangan perusahaan (ROA) yang menunjukkan semakin banyak jumlah aset yang didanai oleh utang maka kinerja keuangan perusahaan menjadi menurun. Kepemilikan manajerial terbukti tidak memengaruhi kinerja pasar perusahaan (Tobin's Q). Akan tetapi, kepemilikan manajerial ditemukan mempunyai pengaruh negatif secara signifikan pada kinerja keuangan perusahan (ROA). Hal ini mengungkapkan bahwa semakin besar jumlah pihak manajemen yang memiliki saham perusahaan akan mengakibatkan kinerja keuangan perusahaan semakin menurun.

\subsection{Pembahasan}

\subsubsection{Propping berpengaruh positif terhadap kinerja keuangan perusahaan}

Berdasarkan hasil penelitian, propping yang diukur dengan transaksi utang usaha dan transaksi utang lain-lain kepada pihak berelasi terbukti berpengaruh positif secara signifikan 
terhadap kinerja keuangan (ROA). Hal ini mengindikasikan bahwa semakin besar transaksi utang usaha dan transaksi utang lain-lain yang dilakukan perusahan kepada pihak berelasi maka kinerja keuangan perusahaan yang diproksi dengan ROA akan semakin tinggi. Makin banyak perusahaan melakukan pinjaman usaha dan pinjaman lain-lain dengan pihak berelasi, makin tinggi kapabilitas perusahaan untuk menghasilkan profitabilitas atas aset yang dimiliki.

Hasil penelitian ini mendukung teori biaya transaksi (transaction cost theory) menurut Williamson (1979) dalam Rindfleisch, (2020) dan efficient transaction hypothesis menurut Gordon et al. (2004) yang memandang suatu perusahaan dapat meningkatkan efisiensi biaya transaksi dengan melakukan transaksi bersifat propping kepada pihak afiliasi sehingga mendorong kinerja perusahaan. Transaksi dengan pihak afiliasi terkait utang usaha dan utang lain-lain yang dilakukan perusahaan terbukti memberikan efisiensi dalam biaya transaksi yang signifikan sehingga mendongkrak capaian laba perusahaan. Transaksi terkait utang usaha dan utang lain-lain dengan pihak berelasi dimungkinkan memiliki prosedur yang relatif lebih mudah, cepat dan mungkin lebih murah.

Transaksi dengan pihak afiliasi terkait utang usaha dan utang lain-lain pada perusahaan manufaktur secara umum berhubungan dengan pembelian bahan baku atau aset tetap kepada pemegang saham mayoritas yang digunakan untuk aktivitas operasional perusahaan. Perusahaan melakukan transaksi terkait utang usaha dan transaksi terkait utang lain-lain dengan pihak berelasi agar meminimalisir pengeluaran atau efisiensi untuk aktivitas operasional perusahaan sehingga mampu memeroleh keuntungan yang meningkat. Pertumbuhan laba yang terus meningkat akan mencerminkan kinerja keuangan perusahaan yang baik. Hasil penelitian ini sependapat dengan penelitian sebelumnya yang menunjukkan bahwa transaksi pihak berelasi terkait pemberian pinjaman berpengaruh positif untuk meningkatkan kinerja keuangan perusahaan melalui praktik manajemen laba (Gordon et al., 2004; Kohlbeck \& Mayhew, 2010)

Transaksi afiliasi terkait liabilitas selain utang usaha ditemukan berpengaruh negatif terhadap ROA yang berarti semakin tinggi transaksi pihak berelasi terkait liabilitas selain utang usaha maka kinerja keuangan perusahaan akan menjadi lebih rendah. Hal ini diduga adanya penambahan utang pihak berelasi jangka panjang yang merupakan beban bunga jatuh tempo yang timbul karena utang perusahaan dan diambil alih oleh pihak berelasi. Semakin besar tingkat utang bunga kepada pihak berelasi maka dapat memberikan dampak negatif terhadap kinerja keuangan perusahaan. Temuan ini sependapat dengan teori agensi yang memandang bahwa pemegang saham mayoritas melakukan kendali aset pemegang saham minoritas agar memeroleh keuntungan sendiri melalui transaksi pihak berelasi bersifat propping (Villalonga \& Amit, 2006; Cheung et al., 2009). Hasil penelitian ini sependapat dengan penelitian terdahulu 
yang menemukan bahwa transaksi pihak berelasi terkait utang berpengaruh negatif terhadap kinerja keuangan perusahaan (Cheung et al., 2009; Chien \& Hsu, 2010).

\subsubsection{Propping berpengaruh positif terhadap kinerja pasar perusahaan}

Berdasarkan hasil penelitian ini, transaksi pihak berelasi liabilitas selain utang usaha terbukti memiliki pengaruh positif secara signifikan terhadap kinerja pasar perusahaan berarti dengan melakukan transaksi terkait utang di luar usaha kepada pihak berelasi dapat mendorong kinerja pasar perusahaan menjadi semakin baik. Transaksi pihak berelasi terkait liabilitas selain utang usaha yang dilakukan oleh perusahaan manufaktur misalnya transaksi uang muka pelanggan dari pihak berelasi, utang terkait dengan jasa konsultasi untuk proyek pengembangan kepada pihak berelasi atau utang terkait dengan tambahan modal kerja yang diberikan oleh pihak berelasi. Melalui transaksi ini, investor memandang baik karena perusahaan dipercaya dapat mengembangkan usaha melalui pinjaman tersebut.

Hasil penelitian ini mendukung teori biaya transaksi (transaction cost theory) menurut Williamson (1979) dalam Rindfleisch, (2020) dan efficient transaction hypothesis Gordon et al. (2004) yang memandang suatu perusahaan dapat meningkatkan efisiensi biaya transaksi dengan melakukan transaksi bersifat propping kepada pihak afiliasi sehingga mendorong kinerja perusahaan. Transaksi pihak berelasi terkait liabilitas selain utang usaha yang dilakukan perusahaan dipandang positif oleh investor sebagai transaksi yang efisien sehingga dapat mendongkrak kinerja pasar perusahaan.

Sebaliknya, transaksi pihak berelasi terkait utang usaha berpengaruh negatif secara signifikan terhadap kinerja pasar perusahaan. Temuan ini membuktikan bahwa semakin besar transaksi antar pihak berelasi terkait dengan utang usaha yang dilakukan oleh perusahaan akan memberikan efek terhadap kinerja pasar menjadi semakin menurun. Tambunan et al. (2017) menyatakan bahwa semakin sering perusahaan melakukan transaksi pihak berelasi maka akan mengakibatkan penurunan nilai pasar atau kinerja perusahaan (Bona-Sánchez, Fernándes-Senra \& Pérez-Alemán, 2017). Kegiatan transaksi pihak berelasi bersifat propping juga memiliki kecenderungan hanya memenuhi kebutuhan kinerja di bursa saham namun tidak akan memengaruhi nilai perusahaan di mata shareholders atau ketertarikan investor terhadap perusahaan (Tambunan et al., 2017).

Dapat diperhatikan nilai rata-rata transaksi utang usaha kepada pihak berelasi memiliki angka yang lebih besar dibandingkan dengan transaksi pihak berelasi utang yang lain, yaitu 4 persen. Transaksi tersebut menunjukkan nilai yang tinggi sehingga investor dapat memandang bahwa kemungkinan perusahaan dikendalikan oleh pemegang saham mayoritas yang mengarah pada pengaturan untuk menguntungkan pihak internal dan pihak berelasi tanpa 
memerhatikan pihak investor. Selain itu, investor akan memberikan reaksi yang ragu akan kemampuan perusahaan dalam melunasi utangnya dikarenakan utang perusahaan yang dilimpahkan dan diselesaikan oleh pihak berelasi sehingga mengakibatkan minat investor menjadi menurun dan menyebabkan turunnya harga saham.

Hasil dari penelitian ini mendukung teori agensi yang memandang bahwa pemegang saham mayoritas melakukan ekspropriasi aset pemegang saham minoritas agar memeroleh keuntungan sendiri melalui transaksi pihak berelasi bersifat propping (Villalonga \& Amit, 2006; Cheung et al., 2009). Hasil penelitian ini sependapat dengan penelitian terdahulu yang menemukan bahwa transaksi pihak berelasi terkait pinjaman dapat menurunkan kinerja pasar perusahaan (Jian \& Wong, 2010; Tambunan et al., 2017).

Transaksi pihak berelasi terkait utang lain-lain ditemukan tidak mempunyai pengaruh secara signifikan terhadap kinerja pasar perusahaan. Cicilia dan Lindrawati (2014) menyatakan bahwa adanya kemungkinan transaksi pihak berelasi terkait utang tidak menjadi perhatian pasar karena transaksi dengan pihak afiliasi terkait utang yang dilakukan oleh perusahaan berada pada tingkat rendah sehingga tidak dapat memberikan pengaruh pada kinerja pasar perusahaan. Dapat dilihat dari nilai rata-rata transaksi utang lain-lain kepada pihak berelasi yang rendah, yaitu hanya 1 persen sehingga dimungkinkan tidak memberikan dampak pada potensi nilai pasar. Investor akan memandang bahwa nilai transaksi pihak berelasi terkait utang lain-lain tidak memberikan keuntungan di masa depan dan menyebabkan investor raguragu untuk melakukan keputusan investasi pada perusahaan. Hasil penelitian ini tidak sependapat dengan penelitian terdahulu yang membuktikan bahwa penerimaan pinjaman dari transaksi afiliasi mempunyai efek positif terhadap kinerja pasar perusahaan (Utama \& Utama, 2014). Namun, hasil penelitian ini sependapat dengan penelitian terdahulu yang menunjukkan bahwa tidak ada pengaruh transaksi pihak berelasi pinjaman terhadap kinerja pasar perusahaan (Pozzoli \& Venuti, 2014; Utama et al., 2010; Khairunnisa, 2018; Cicilia \& Lindrawati, 2014).

\section{Kesimpulan, Keterbatasan, dan Saran}

Kesimpulan yang diperoleh dari hasil analisis dan pembahasan adalah transaksi pihak berelasi bersifat propping yang diukur dengan transaksi pihak berelasi utang usaha terdapat pengaruh positif terhadap kinerja keuangan dan berpengaruh negatif terhadap kinerja pasar 
perusahaan. Sementara itu, propping yang diukur dengan transaksi pihak berelasi terkait utang lain-lain memiliki pengaruh positif terhadap kinerja keuangan perusahaan tetapi tidak terbukti memengaruhi kinerja pasar perusahaan. Selain itu, propping yang diukur dengan transaksi pihak berelasi terkait liabilitas selain utang usaha berpengaruh negatif terhadap kinerja keuangan namun berpengaruh positif terhadap kinerja pasar perusahaan.

Hasil dari penelitian memberikan bukti empiris aplikasi teori biaya transaksi dan teori agensi bahwa transaksi pihak berelasi bersifat propping pada perusahaan manufaktur di Indonesia mendorong ataupun menurunkan kinerja perusahaan. Hasil temuan ini dapat menjadi dasar pertimbangan bagi perusahaan dalam pengambilan keputusan terkait transaksi pihak berelasi bersifat propping mengenai adanya risiko tingkat bunga utang yang tinggi kepada pihak berelasi karena dapat memiliki kemungkinan ketidakmampuan perusahaan untuk melunasi utang sehingga memengaruhi kinerja keuangan perusahaan. Bagi pelaku pasar, temuan ini dapat menjadi dasar pertimbangan dalam berinvestasi dengan berhati-hati terhadap perusahaan yang memiliki transaksi terkait utang usaha kepada pihak afiliasi karena dapat menurunkan kinerja pasarnya. Bagi regulator seperti BapepamLK dan OJK, temuin ini juga dapat menjadi dasar pertimbangan dalam pengaturan dan pengawasan tentang transaksi pihak berelasi terkait utang di perusahaan yang terbukti memengaruhi kinerja perusahaan.

\subsection{Keterbatasan}

Dalam penelitian ini memiliki keterbatasan, yaitu mengabaikan variasi industri karena dalam perusahaan manufaktur terdapat beberapa sub sektor yang dimungkinkan memiliki perilaku keuangan maupun transaksi pihak berelasi yang berbeda antar kelompok industri. Selanjutnya, penelitian ini juga mengabaikan tipe pihak berelasi yang terlibat, apakah individual atau institusi.

\subsection{Saran}

Berdasarkan keterbatasan penelitian, untuk penelitian mendatang disarankan dapat memerhatikan keterbatasan penelitian tersebut misalnya fokus pada satu sektor industri dengan memerhatikan tipe pihak-pihak berelasi, misalkan membedakan transaksi pihak berelasi yang dilakukan dengan individual dan institusi (perusahaan).

\section{Daftar Pustaka}

Agusti, R., \& Pramesti, T. (2009). Pengaruh asimetri informasi, ukuran perusahaan, kepemilikan manajerial terhadap manajemen laba. Jurnal Ekonomi, 17(01), 1-10. 
Al-matari, E. M., Al-Swidi, A. K., \& Fadzil, F. H. B. (2014). The measurements of firm performance's dimensions. Asian Journal of Finance and Accounting, 6(1), 24-49.

Apriansyah, F. (2016). Pengaruh ukuran perusahaan, leverage dan rentabilitas terhadap equity risk premium pada perusahaan manufaktur yang terdaftar di bursa efek indonesia. University of Lampung Site. Diperoleh dari http://digilib.unila.ac.id/id/eprint/21558

Berkman, H., Cole, R. A., \& Fu, L. J. (2009). Expropriation through loan guarantees to related parties: Evidence from china. Journal of Banking and Finance, 33(1), 141-156.

Bona-Sánchez, C., Fernández-Senra, C. L., \& Pérez-Alemán, J. (2017). Related party transactions, dominant owners and firm value. BRQ Business Research Quarterly, 20(1), 4-17.

Chen, C., \& Wu, C. (2010). Related party transactions and ownership concentration: Theory and evidence. E-Leader Conference, 57, 1-8.

Cheung, Y. L., Jing, L., Lu, T., Rau, P. R., \& Stouraitis, A. (2009). Tunneling and propping up: An analysis of related party transactions by chinese listed companies. Pacific Basin Finance Journal, 17(3), 372-393.

Chien, C., \& Hsu, J. C. S. (2010). The role of corporate governance in related party transactions. www.ssrn.com. doi:10.2139/ssrn.1539808

Christiawan, Y. J., \& Tarigan, J. (2005). Kepemilikan manajerial: Kebijakan hutang, kinerja dan nilai perusahaan. Jurnal Akuntansi Dan Keuangan, 9(1), 1-8.

Cicilia, \& Lindrawati. (2014). Pengaruh struktur kepemilikan perusahaan, corporate governance dan transaksi pihak berelasi terhadap daya informasi akuntansi pada perusahaan manufaktur yang terdaftar di BEI. Jurnal Akuntansi Kontemporer, 6(2), 224-255.

Friedman, E., Johnson, S., \& Mitton, T. (2003). Propping and tunneling. Journal of Comparative Economics, 31, 732-750.

Gordon, E. A., Henry, E., \& Palia, D. (2004). Related party transactions: Associations with corporate governance and firm value. Diakses dari www.ssrn.com.

Gujarati, D.N., Porter, D. C. (2009). Basic Econometrics. NewYork:McGraw-Hill/Irwin.

Jia, N., Shi, J., \& Wang, Y. (2013). Coinsurance within business groups: Evidence from related party transactions in an emerging market. Management Science, 59(10), 2295-2313.

Jian, M., \& Wong, T. J. (2010). Propping through related party transactions. Review of Accounting Studies, 15(1), 70-105.

Kamal, M. B. (2017). Pengaruh receivable turn over dan debt to asset ratio (DAR) terhadap return on asset $(\mathrm{ROA})$ pada perusahaan pertanian yang terdaftar di bursa efek indonesia (BEI). Jurnal IImiah Manajemen Dan Bisnis, 17(2), 68-81.

Khairunnisa, M. (2018). Pengaruh transaksi pihak-pihak hubungan istimewa terhadap kinerja perusahaan. University of Lampung Site. Diperoleh 
darihttp://digilib.unila.ac.id/id/eprint/31617.

Kohlbeck, M., \& Mayhew, B. W. (2010). Valuation of firms that disclose related party transactions. Journal of Accounting and Public Policy, 29(2), 115-137.

Luh, N., Mariani, L., Yudiaatmaja, F., \& Yulianthini, N. N. (2016). Pengaruh profitabilitas dan leverage terhadap return saham. Jurnal Manajemen Indonesia, 4(1), 1-10.

Otoritas Jasa Keuangan. (2020). Transaksi Afiliasi dan Transaksi Benturan Kepentingan (2020). Diperoleh darihttps://www.ojk.go.id/id/regulasi/Documents/Pages/Transaksi-Afiliasi-danTransaksi-Benturan-Kepentingan/POJK 42-2020.pdf

Pagalung, G. (2004). Transaction cost, agency theory, dan stakeholder theory dalam teori (desain) organisasional: Kajian asumsi-asumsi dasar. Jurnal Bisnis Dan Akuntansi, 6(2), $138-150$.

Pozzoli, M., \& Venuti, M. (2014). Related party transactions and financial performance: Is there a correlation? Empirical evidence from italian listed companies. Open Journal of Accounting, 03(01), 28-37.

Rindfleisch, A. (2020). Transaction cost theory: past, present and future. AMS Review, 10(1-2), 85-97.

Sudiyatno, B., \& Puspitasari, E. (2010). Tobin's q dan altman z-score sebagai indikator pengukuran kinerja perusahaan. Kajian Akuntansi, 2(1), 9-21.

Supatmi. (2020). Pengaruh transaksi pihak berelasi terhadap kinerja perusahaan dengan koneksi politik sebagai pemoderasi. Disertasi Yang Tidak Dipublikasikan (Universitas Brawijaya, Malang).

Supatmi, Sutrisno, T., Saraswati, E., \& Purnomosidhi, B. (2019). The effect of related party transactions on firm performance: The moderating role of political connection in indonesian banking. Business: Theory and Practice, 20(2003), 81-92.

Tambunan, M. E., Siregar, H., \& Manurung, A. H. (2017). Related party transactions and firm value in the business groups in the indonesia stock exchange. Journal of Applied Finance and Banking, 7(3), 1-20.

Triyono, A. (2020). pengaruh besaran transaksi pihak berelasi terhadap nilai perusahaan pada perusahaan yang terdaftar di bursa efek indonesia. Jurnal Penelitian Teori Dan Terapan Akuntansi, 5(1), 1-26.

Utama, S., Utama, C. A., Yuniasih, R. (2010). Related party transaction - efficient or abusive: Indonesia evidence. Asia Pacific Journal of Accounting and Finance, 1(1), 77-102.

Utama, C. A., \& Utama, S. (2014). Corporate governance, size and disclosure of related party transactions, and firm value: Indonesia evidence. International Journal of Disclosure and Governance, 11(4), 341-365.

Villalonga, B., \& Amit, R. (2006). How do family ownership, control and management affect firm 
value? Journal of Financial Economics, 80(2), 385-417.

Widianto, H. S. (2011). Pengaruh profitabilitas, likuiditas, leverage, aktivitas, ukuran perusahaan, dan corporate governance terhadap praktik pengungkapan sustainability report (studi pada perusahaan - perusahaan yang listed (go-public) di bursa efek indonesia (BEI). Jurnal Akuntansi, 1-83.

Winarno, W. W. (2015). Analisis ekonometrika dan statistika dengan eviews. Yogyakarta:UU STIM YKPN.

Wong, R. M. K., Kim, J., \& Lo, A. W. Y. (2015). Are related-party sales value-adding or valuedestroying? Evidence from china. Journal of International Financial Management and Accounting, 26(1), 1-38.

Yuliyanti, L. (2019). Pengaruh good corporate governance dan pengungkapan corporate social responsibility terhadap nilai perusahaan. Jurnal Pendidikan Akuntansi \& Keuangan, 2(2), 21. 